\title{
The Strange Case of Byron Preiss Visual Publications
}

\begin{abstract}
Between 1976 and 1979 Byron Preiss operated as a book packager specializing in graphic novels, bringing comics creators together on original stories and licensed properties and delivering the finished product to publishing houses. Far from being praised for his efforts, Preiss was attacked by fans and comics professionals for betraying the very medium he professed to uplift. This article explains the industrial shifts behind the rise of Byron Preiss Visual Publications and book-format comics, as well as accounting for the hostility directed against Preiss, a level of vitriol that increased after his collaborators on Empire (1978) expressed their dismay at the changes he made to the graphic novel before publication.
\end{abstract}

Byron Cary Preiss (1953-2005) was one of the most controversial figures in US comics in the second half of the 1970s. His company Byron Preiss Visual Publications (BPVP) produced nine comics-related books between 1976 and 1979, published and distributed via the book trade and marketed (and priced) for adult readers. Most of these were advertised as 'graphic novels. ' The narratives in BPVP's books juxtaposed verbal and visual material in differing ratios depending on the particular text, but several contained long comics narratives written and drawn by established comics creators. BPVP claimed to be bidding to win cultural legitimacy for the comics form, a theme scholars have examined and advanced themselves over the last thirty years, ${ }^{2}$ but in the 1970 s Preiss was pilloried as a self-important arriviste. His books jettisoned various comics conventions (e.g. speech balloons) and he was criticized for betraying the very medium he professed to uplift; in 1978 one reader called him the "greatest enemy"3 that comics faced. Despite committing himself to creators' rights, Preiss

\footnotetext{
${ }^{1}$ A useful summary of the arguments for and against the term 'graphic novel' can be found in Hugo Frey and Jan Baetens, The Graphic Novel: An Introduction (New York: Cambridge University Press, 2015), 1-5. I use the phrase without qualification, reflecting the terminology that Preiss, his collaborators, and his readers used themselves.

${ }^{2}$ See Charles Hatfield, Alternative Comics: An Emerging Literature (Jackson: University Press of Mississippi, 2005); Roger Sabin, Adult Comics: An Introduction (London: Routledge, 1993); Joseph Witek, Comic Books as History: The Narrative Art of Jack Jackson, Art Spiegelman, and Harvey Pekar (Jackson: University Press of Mississippi, 1989).

${ }^{3}$ Ron Harris, "Argh," CAPA-alpha, 167 (Sept. 1978), [1.57]. Where sources lack pagination I have provided my own, indicated with square brackets. Numbers have been deduced by counting in from the front of the text, taking the front cover as page one and counting every side as a page. CAPAalpha generates specific difficulties, a monthly collaborative fan publication sometimes more than
} 
insisted on formal restraints and intrusively editing his books, something that rankled fans and professionals alike. BPVP was well known in the 1970s comics world - as with Marvel and DC, comics fanzine The Comic Reader dedicated a column to the company's latest releases - but Preiss's publications have received scant attention from academics or, indeed, anyone else. ${ }^{4}$

Despite being virtually invisible in existing scholarship, there are good reasons to look again at BPVP's working practices and reception, since the strange case of Byron Preiss underlines how complex and contested the attempt to turn comics into graphic novels was during the 1970s. The protests against Preiss contradict the dominant narrative in comics historiography, where the relative legitimacy, visibility, and broad readership of comics in the twenty-first century can be attributed to the increased publication of comics in soft- and hardcover formats, what comics scholar Jan Baetens calls the graphic novel's "bookishness."5 Trade publishing brings comics narratives closer to the material dimensions of literary classics, at least as those classics have been physically reprinted for most of the twentieth century (i.e. in book form):

It became the conventional wisdom [in the late 1990s] that the physical format of graphic novels enabled comics to reach a wider range of readers. The familiarity of the 'book' format seemed to make comics a more comfortable purchase, or more respectable reading material. The graphic novel format also generally meant that readers could be assured that they were buying an experience that had a beginning, middle, and end....

700 pages long and compiled from multiple newsletters; contributions to CAPA-alpha were inconsistently paginated and later mailings were typically divided into discrete bindings. I have ignored internal pagination in the newsletters themselves and attributed page numbers using the system referred to above. When an issue has been partitioned I use two numbers separated by a period: the first indicates which binding, the second represents the page/s in that binding. Unbound contributions to CAPA-alpha are indicated with [Insert] and my citations refer to the page numbers printed on those newsletters themselves, though where these are unpaginated I have allocated page numbers myself.

${ }^{4}$ At two pages, BPVP is afforded more space in Frey and Baetens, Graphic Novel, 69-70 than in most other books. Brief references to BPVP and its graphic novels can be found in Brannon Costello, Neon Visions: The Comics of Howard Chaykin (Baton Rouge: Louisiana State University Press, 2017), 21, 46; R. C. Harvey, The Art of the Comic Book: An Aesthetic History (Jackson: University Press of Mississippi, 1996), 109, 145; Harvey Kurtzman with Michael Barrier, From Aargh! To Zap! Harvey Kurtzman's Visual History of the Comics (New York: Prentice Hall Press, 1991), 75.

5 Jan Baetens, "Graphic Novels," in Leonard Cassuto, ed., The Cambridge History of the American Novel (Cambridge: Cambridge University Press, 2011), 1151.

${ }^{6}$ Randy Duncan, Matthew J. Smith, and Paul Levitz, The Power of Comics: History, Form, and Culture, 2nd ed. (London: Bloomsbury Academic, 2015), 87. 
In conjunction with this ideology of completeness, the single-book format facilitated the study of comics in schools, colleges, and universities, as well as reviews in broadsheet newspapers and literary journals. ${ }^{7}$

I would not reject this narrative entirely, but it is inadequate in its current incarnation and the reception of BPVP underlines that the transformation of comics into graphic novels was a fraught and contested process. Comics scholars have constructed the 1960s and 1970s as a period when stakeholders in the comics industry imported various mechanisms (canon formation, the identification of auteurs) from other cultural forms into comics in order to cultivate the sensibility that their preferred medium was a valuable art-form; in Demanding Respect: The Evolution of the American Comic Book (2009) the comics scholar Paul Lopes argues this sensibility was then exported out to US culture more generally. ${ }^{8}$ The hostile response to Byron Preiss's graphic novels indicates there was no concerted, uniform will amongst fans, creators, and publishers to change the status of comics in American society. Attempts to do so were greeted with the suspicion that something integral to comics was being abandoned by BPVP's efforts to elevate the medium through book publication.

The 1970s fans whose responses are recorded in this article prefigure the argument made in Christopher Pizzino's Arresting Development: Comics at the Boundaries of Literature (2016). Pizzino questions the historical narrative that the respect accorded to comics by creators and fans was gradually taken up by US culture at large; he warns "this model can ignore the degree to which 'internal' legitimation of a medium actually means applying external standards that have been used to devalue it." 9 This was the substance of many of Preiss's critics: BPVP's books were trying to deracinate themselves from the implication they might be comics. They were right, since Preiss and some of his collaborators (specifically James Steranko) acknowledged they didn't want their graphic novels to use certain formal conventions indelibly associated with comics, such as hand-written lettering, speech balloons, or panel layouts. In order to convince publishing houses to put out graphic novels, Preiss sacrificed the most visible markers of their comic-ness, earning the ire of fans and creators who complained the texts he edited weren't comics at all.

\footnotetext{
${ }^{7}$ Paul Lopes, Demanding Respect: The Evolution of the American Comic Book (Philadelphia: Temple University Press, 2009), 132; Roger Sabin, Comics, Comix \& Graphic Novels (London: Phaidon, 1996), 165.

${ }^{8}$ Lopes, Demanding Respect, xi.

${ }^{9}$ Christopher Pizzino, Arresting Development: Comics at the Boundaries of Literature (Austin: University of Texas Press, 2016), 22-45.
} 
In Arresting Development Pizzino critiques the journalistic and scholarly claims that US comics have 'grown up' or 'come of age,' maturing “from a despised medium ... to a respectable kind of reading." Pizzino calls this comics' Bildungsroman discourse, personifying the medium as a human being progressing through childhood and troubled adolescence to an adulthood where social status is secured in the world. In other words, comics recapitulate ontogeny, a teleological narrative culminating in "an earned measure of cultural legitimacy." Pizzino rejects this metaphor for rendering the history of comics as inevitably and organically developing across the decades, obscuring comics' societal besiegement during the twentieth century (burnings and allegations of stoking delinquency) and ignoring the ongoing devaluation of this cultural form. ${ }^{10}$

Pizzino extrapolates broader claims from the status anxiety of American comics culture, contending that a quality of autoclasm or self-shattering is immanent in comics' very form. This claim seems somewhat indiscriminate given the sheer variety of contexts in which comics are and have been made, but it seems fair to identify this autoclastic tension in specific texts. As we will see when we consider the production history of Empire (1978), a text written by SF luminary Samuel R. Delany, illustrated by Howard Chaykin, and edited by Preiss, it was indeed possible for a graphic novel to be the site of clashes over what was disreputable or undesirable in a comic, embodied in the scarred version of Empire published to the dismay of the writer and artist. Pizzino puts graphic novels at the heart of Bildungsroman discourse, arguing that journalistic accounts constructing these privileged texts as exceptional outliers confirm the prejudice that comics as a whole are "naturally inferior and immature." The "legitimacy the graphic novel possesses," Pizzino elaborates, "is conflicted and unstable." 11 This article extends Pizzino's insights into an older period of graphic novel production (Arresting Development's case studies are drawn from the 1980s and after) and shows that the tensions he sees immanent to the form of comics were the subject of vivid debates in the 1970s comics world too.

Elsewhere I refer to this transformation of comics into graphic novels as the novelization of comics. ${ }^{12}$ I am attracted to this formulation because it underlines that the emergence of graphic novels was not a one-off event but a bundle of interconnected processes driven - and resisted - by actors wielding divergent forms of institutional power

\footnotetext{
${ }^{10}$ Ibid., 30, 22.

${ }^{11}$ Ibid., 22-45.

${ }^{12}$ See my forthcoming monograph from Rutgers University Press.
} 
and positioned at every stage of the communications circuit. ${ }^{13}$ The novelization of comics was propelled by the people who wrote and drew graphic novels, but also by editors who prepared pages for production, technicians who printed them, and publishing houses investing capital in the hope of commercial success. Consumers and readers were also crucial for paying money that might underwrite future books and for acclaiming long comics narratives as novels. Although these consumers and readers wielded less power individually than the creative workers who brought graphic novels to market there can be no question of their importance in influencing which comics got published. Especially relevant for this project, fans were crucial in determining which books of comics labelled 'graphic novels' were accepted as such. ${ }^{14}$

The cohort of readers who self-identify as comics fans (collectively referred to as 'fandom') occupy a unique position in the comics world. Fans are consumers whose heightened affective investment in the comics form is marked by comics collecting, attending conventions, writing to creators and editors, setting up and joining fan clubs, and contributing to 'fanzines' (fan magazines). Underpinning these acts is the desire to share an appreciation of comics and affirm their deserved status as objects of passion. From the point of view of the comics industry in the 1970s, fans were a minority of consumers, but their importance was significant and growing. Fans represented a potential source of labour, and it was common for them to become workers in the industry. ${ }^{15}$ Fans were also content providers, offering suggestions for future stories. ${ }^{16}$ Most importantly, fans were key consumers, and their will-to-

\footnotetext{
${ }^{13}$ I have in mind the communications circuit proposed in Robert Darnton, The Kiss of Lamourette: Reflections in Cultural History, rev. ed. (London: Faber, 1990), 107-36, and revised in Thomas R. Adams and Nicholas Barker, "A New Model for the Study of the Book," A Potencie of Life: Books in Society (London: British Library, 1993), 1-39. These essays are excerpted in David Finkelstein and Alistair McCleery, eds., The Book History Reader, 2nd ed. (London: Routledge, 2006), 9-26, 47-65. ${ }^{14}$ This picture of the collective nature of comics production, distribution, and reception is indebted to the 'comics world' model that Bart Beaty espouses, which in turn is indebted to sociologist Howard Becker's concept of the 'art world.' See Bart Beaty, Comics Versus Art (Toronto: University of Toronto Press, 2012); Howard S. Becker, Art Worlds, anniversary edition (Berkeley: University of California Press, 2008). Although Beaty draws on Becker more than other critics, earlier versions of the 'art world' model had been proposed by the philosopher of art Arthur Danto and art critic George Dickie.

${ }^{15}$ Marco Arnaudo, The Myth of the Superhero, trans. Jamie Richards (Baltimore: Johns Hopkins University Press, 2013), 153; Will Brooker, Batman Unmasked: Analyzing a Cultural Icon (New York: Continuum, 2000), 253; Lopes, Demanding Respect, 97; Matthew Pustz, Comic Book Culture: Fanboys and True Believers (Jackson: University Press of Mississippi, 1999), 46.

${ }^{16}$ Jeffrey A. Brown, Black Superheroes, Milestone Comics, and their Fans (Jackson: University Press of Mississippi, 2001), 11; Pustz, Comic Book Culture, 37-48, 82, 167.
} 
completism made them relatively dependable purchasers of every issue in an ongoing series (or a new title featuring a favoured character or by a fêted creator). ${ }^{17}$

In the 1970s a distribution system emerged that saw comics sold through specialist shops, venues frequented almost exclusively by fans of comics and related media. The growth of this 'direct market' underscored what many stakeholders in the North American comics world already knew, that fans would spend more money on comics than the average purchaser (fans were older and hence had more disposable income). This made them a lucrative group for comics companies to target, especially given the industry's "shrinking" overall sales; the symbolic nadir of this period was the 'DC Implosion' of 1978 that saw DC Comics cancel 40 percent of its titles and announce layoffs of its creative staff. Historian Bradford W. Wright notes that as "comic books lost much of their mass audience, they increasingly became the preserve of a fan subculture...."18 Publishers eavesdropped on conversations between fans and responded accordingly, even if a few professionals dismissed the fans' importance to the industry as a whole. ${ }^{19}$ The fractiousness of such exchanges was partly a result of the intense intimacy between the makers of comics and their consumers: fandom had always created opportunities for these two groups to interact and in the 1970s new fanzines (The Buyer's Guide to Comics Fandom, The Comics Journal) and events (the San Diego Comic-Con) commanded the attention of greater numbers of fans than ever before. ${ }^{20}$ Where the comics world was concerned, fandom was not a marginalized, esoteric irrelevance but a deep repository of critique and collective memory - which is not to say that dialogue between fans was always constructive, measured, and relevant, as Byron Preiss learnt to his cost.

Preiss had the power and opportunity to act as a 'producer' of graphic novels because of the full flowering of 'blockbuster' practices in the book trade. In the 1970s cross-media licensing became an industry norm and a new breed of literary agent wielded sizable creative and legal power. So what was blockbuster publishing and how did it arise?

\footnotetext{
${ }^{17} \mathrm{Jim}$ Shooter, Interview with Kim Thompson, The Comics Journal, 40 (June 1978), 45. The Comics Journal hereafter abbreviated to TCJ.

${ }^{18}$ Hatfield, Alternative Comics, 20-30; Bradford W. Wright, Comic Book Nation: The Transformation of Youth Culture in America, rev. ed. (Baltimore: Johns Hopkins University Press, 2003), 253-60; Sean Howe, Marvel Comics: The Untold Story (New York: HarperCollins, 2012), 212.

${ }^{19}$ See the comments by writer Roy Thomas and publisher Jim Warren in Gary Brown, "Ibid," CAPAalpha, 122 (Dec. 1974), [41] and Bill Schelly, The Golden Age of Comic Fandom, rev. ed. (Seattle: Hamster Press, 1999), 89, 92 respectively.

${ }^{20}$ See Schelly, Golden Age of Comic Fandom for an enlightening history written from the perspective of a fan who participated in many key events of the 1960s and 1970s. An account of how comics fans responded to industrial change in the mid-1970s is provided in Michael Goodrum, Superheroes and American Self Image: From War to Watergate (London: Routledge, 2016), 177-215.
} 


\section{Blockbuster Publishing and Book Packagers}

Starting in 1960 the US book trade entered a period of mergers and acquisitions as presses were bought up "by huge conglomerates involved in activities other than publishing." "1 Thomas Whiteside's The Blockbuster Complex (1981) provides a useful contemporary perspective, albeit one fixed on the conglomeration of the book trade to the exclusion of older, surviving publishing models. Whiteside notes that once multinationals invested unprecedented sums of money they expected more "financially rational structures" and "long-range financial-planning programs." ${ }^{22}$ By the 1970s conglomerated publishing houses wanted to maximize profit at the moment of a book's release, a state of affairs forced by the severe decline of independent bookstores and the rapid growth of chains such as B. Dalton and Waldenbooks. These chains sold their stock quickly and at high volume, taking advantage of computerized sales and inventory tracking so that information on titles selling well in one region was swiftly communicated to stores nationwide. ${ }^{23}$ Mediocre sellers were quickly removed to create space for faster-selling stock. New books were typically "dead in days or weeks." Publishers saturated the market with new titles in the hope that the next "big book" (with sales in the region of 300,000 copies) would outweigh the average performance of new titles (1,200 copies a year). ${ }^{24}$ The release of a new book was turned into a media event via advertising and placing authors on talk shows. ${ }^{25}$ New titles were meant to be as attentiongrabbing as possible and the chain stores attracted a wider range of customers than the smaller independent bookstores: in this climate, the mass appeal and novelty value of bookformat comics made them a tantalizing prospect for publishers, and East Coast trade presses ventured into the market with various titles, including Burne Hogarth's Tarzan of the Apes (1972) and Jungle Tales of Tarzan (1976), Stan Lee and Jack Kirby's The Silver Surfer (1978), and Jules Feiffer's Tantrum (1979).

\footnotetext{
${ }^{21}$ Frederick G. Kilgour, The Evolution of the Book (New York: Oxford University Press, 1998), 14445. See also John B. Thompson, Merchants of Culture: The Publishing Business in the Twenty-First Century, 2nd ed. (Cambridge: Polity Press, 2012), 105.

22 Thomas Whiteside, The Blockbuster Complex: Conglomerates, Show Business, and Book Publishing (Middletown, CT: Wesleyan University Press, 1981), 15, 192.

${ }^{23}$ Ibid., 39-46, 111.

${ }^{24}$ Ibid., 19; Leonard Shatzkin, In Cold Type: Overcoming the Book Crisis (Boston: Houghton Mifflin, 1982), 2-12, 68, 73; Ken Gelder, Popular Fiction: The Logics and Practices of a Literary Field (London: Routledge, 2004), 1 n.7.

${ }^{25}$ Lewis A. Coser, Charles Kadushin, and Walter W. Powell, Books: The Culture and Commerce of Publishing (New York: Basic Books, 1982), 41, 212-15.
} 
Another key transformation in North American publishing was the rise of softcover houses. The established presses earned relatively little income from hardback books; they made much more money selling the reprint rights for popular hardcovers to softcover publishers. ${ }^{26}$ To circumvent these high licensing fees, paperback houses moved further into original book publication. ${ }^{27}$ Gil Kane's 121-page Blackmark, published by Bantam Books in 1971, represents an early example of how original graphic novels were attractive to softcover publishers; in 1979 Bantam published Byron Preiss's heavily illustrated fantasy novel Dragonworld. ${ }^{28}$ Nonetheless, most book-format comics published by paperback houses were reprint editions, such as the two volumes of Green Lantern Co-Starring Green Arrow written by Denny O'Neil with art by Neal Adams. ${ }^{29}$ The first was published in January 1972 and the second in June the same year, both from the Paperback Library and stating they contained "two complete novels" on their covers. ${ }^{30}$ The Green Lantern Co-Starring Green Arrow comic was at the leading edge of the 'relevancy' movement that saw mainstream superhero comics grappling with social issues such as racism, drugs, poverty, and labour unrest, a trend reported in the New York Times, the Wall Street Journal, and Newsweek. ${ }^{31}$ The Green Lantern paperbacks were conceived by Preiss and aimed at "the college market," 32 as confirmed by DC editor Carmine Infantino in 1970:

A paperback house is going to do up the Green Lantern/Green Arrow series, the whole series. They feel that strongly about what [O'Neil] has done here. They're going to take it and develop it for colleges. Berkeley has asked us for twenty thousand copies of the first print on this thing. Unfortunately our plates were finished and we couldn't give them to them. There's been a big demand for these books. ${ }^{33}$

\footnotetext{
${ }^{26}$ Whiteside, Blockbuster Complex, 21.

${ }^{27}$ Thompson, Merchants of Culture, 37.

${ }^{28}$ Gil Kane [with Archie Goodwin], Blackmark (New York: Bantam Books, 1971); Byron Preiss and Michael Reaves, writers, and Michael Zucker, illustrations, Dragonworld (New York: Bantam Books, 1979).

${ }^{29}$ The Green Lantern series was renamed Green Lantern Co-Starring Green Arrow during O'Neil and Adams's run on the title.

${ }^{30}$ Denny O'Neil, writer, Neal Adams and Frank Giacola, artists, Green Lantern Co-Starring Green Arrow Volume 1 (New York: Paperback Library, 1972); Denny O’Neil, writer, Neal Adams, Frank Giacola, and Dan Adkins, artists, Green Lantern Co-Starring Green Arrow Volume 2 (New York: Paperback Library, 1972). Vol. 1 begins with an origin story written by John Broome with art by Gil Kane and Joe Giella, "SOS Green Lantern!" (1959).

${ }^{31}$ Goodrum, Superheroes and American Self Image, 178-84.

${ }^{32}$ Byron Preiss, Interview with George Olshevsky, Collector's Dream, 1, 5 (Summer 1978), 92-99.

${ }^{33}$ Transcript of The Alex Bennett Show broadcast on WMCA on 23 Nov. 1970 reproduced in John Nyman, "Mutha Load," CAPA-alpha, 76 (Feb. 1971), [6] [Insert].
} 
Reality proved somewhat different: Preiss conceded "they did not sell very well." "34

Publishing house Simon and Schuster was at the leading edge of conglomeration; in 1975 it was bought by Gulf \& Western, a corporation with interests in mining, automobile parts, and filmmaking. It was run by Richard Snyder, a proselytizer for blockbuster publishing trends who lauded the chain stores for making the book trade less aloof and elitist. ${ }^{35}$ Under their young adult imprint Fireside, Simon and Schuster brought out a line of books reprinting Marvel comics; between 1974 and 1979 eleven of these 'Origins books' were published, so-called because the first volume was Origins of Marvel Comics. ${ }^{36}$ In 1978 Preiss expressed his gratitude that the Origins books netted sales of 90,000 copies because this compelled major publishers to "acknowledge that there is an audience for comics in book form." 37 Publishers could make huge sums selling the movie rights for their titles, both in terms of licensing fees and extra sales from added publicity, and Snyder boasted that Simon and Schuster generated "the software of the television and movie media." Many publishing houses established offices in California to get "in on the ground floor of movie tie-ins," such as the West Coast imprint Simon and Schuster Productions. ${ }^{38}$ Fireside's publication of Stan Lee and Jack Kirby's original graphic novel The Silver Surfer in 1978 may well be attributable to the search for synergy with the film industry. Rumours of a Silver Surfer film went back to $1972,{ }^{39}$ and in 1979 it actually seemed to be happening:

Stan has finally put together a deal to make a feature film of THE SILVER SURFER. Lee Kramer of L-K Productions, in a 50-50 partnership with Marvel Comics Group, has managed to find half the backing for the film's proposed $\$ 25,000,000$ among British financiers and expects no trouble in finding the rest. Stan has written the first draft of the film. ... The film should begin production next year... ${ }^{40}$

The film was reportedly an adaptation of the Silver Surfer graphic novel. ${ }^{41}$ Given the book's length and self-contained narrative, it is reasonable to think the writer and Simon and Schuster had this endpoint in mind during its gestation. The book certainly fitted the

\footnotetext{
${ }^{34}$ Preiss, Interview with G. Olshevsky, 92-99.

${ }^{35}$ Whiteside, Blockbuster Complex, 64-65, 85-87, 115-120.

${ }^{36}$ For a full list, see Robert G. Weiner, Marvel Graphic Novels and Related Publications: An Annotated Guide to Comics, Prose Novels, Children's Books, Articles, Criticism and Reference Works, 1965-2008 (Jefferson, NC: McFarland, 2008).

${ }^{37}$ Preiss, Interview with G. Olshevsky, 96-97.

${ }^{38}$ Whiteside, Blockbuster Complex, 3, 19, 52-87, 115-120.

39 "Et Al," The Comic Reader, 91 (Nov. 1972), 14. The Comic Reader hereafter abbreviated to TCR.

40 "Media Review," TCR, 174 (Nov. 1979), 5-6.

41 "Newswatch," TCJ, 51 (Nov. 1979), 10. See also "Marvel News," TCR, 183 (Sept. 1980), 5.
} 
blockbuster logic of publishing media-savvy authors, since Lee was "an increasingly regular sight on television talk shows and in newspapers." ${ }^{2}$ The Silver Surfer motion picture never materialized but Snyder's enthusiasm for comics-based Hollywood tie-ins was undiminished: Ridley Scott's film Alien (1979) and Steven Spielberg's madcap comedy 1941 (1979) were adapted into book-format comics either published or distributed by Simon and Schuster. ${ }^{43}$

The conglomeration of the book trade did not lead to the establishment of internally borderless corporate empires where intellectual properties passed seamlessly from publishers to film studios owned by the same multinational. This is partially due to the creative control wielded by a new kind of agent moving into the book trade from the film industry and/or legal practice. These agents ensured they got the best possible deals across corporations, not within them. Further, with in-house editors spending decreasing amounts of time actually editing books, agents came to exercise unprecedented creative authority. These agents, known as "book packagers," would generate ideas for authors and bring writers, studios, and fashionable subjects into conversation. Packagers could have a book's licensing rights finalized before the first draft was finished - in some cases, before writing had begun. ${ }^{44}$ The term was another migrant from Hollywood cinema, where, in the 1960s, executive producers orchestrating similar contractual complexes were described as 'packaging a deal. ${ }^{, 45}$ This was the role played by Byron Preiss, styled as a "graphic story producer" 46 or "visual producer" 47 akin to "the producer of motion pictures." 48

\section{"The Advent of the Producer in the Field of Graphic-Storytelling"49}

Byron Preiss, a graduate of the University of Pennsylvania and Stanford Graduate School of Communication, had been an intern at DC when he proposed the paperback edition of Green Lantern Co-Starring Green Arrow. DC had made Preiss "director of ... a comics education

\footnotetext{
${ }^{42}$ Howe, Marvel Comics, 214.

${ }^{43}$ Archie Goodwin, writer, and Walt Simonson, art, Alien: The Illustrated Story (New York: Heavy Metal Communications, 1979); Allan Asherman, adaptor, Stephen Bissette and Rick Veitch, art, 1941: The Illustrated Story (New York: Heavy Metal / Pocket Books, 1979).

${ }^{44}$ Coser, Kadushin, and Powell, Books, 182, 265-66, 301; Thompson, Merchants of Culture, 62-63.

${ }^{45}$ Becker, Art Worlds, 88.

${ }^{46}$ Byron Preiss, "Nine Visions in Amber," Mediascene, 28 (Nov.-Dec. 1977), 7; Dave Scroggy, "Wugga Wugga," The Buyer's Guide to Comic Fandom, 233 (5 May 1978), 4; Tony Robertson, Letter, TCJ, 40 (June 1978), 17. The Buyer's Guide to Comic Fandom is hereafter abbreviated to $T B G$.

${ }^{47}$ Scroggy, "Wugga Wugga," 4.

${ }^{48}$ Tony Robertson, Letter, TCJ, 40 (June 1978), 17.

${ }^{49}$ Ibid., 17.
} 
program" called Edugraphics and he collaborated with creator James Steranko on a comic about drug addiction published in tabloid form and distributed to children in Philadelphia. ${ }^{50}$ Preiss briefly wrote comics for other publishers; in the mid-1970s National Lampoon serialized his comic strip One Year Affair, a fifty-two-episode musing on modern dating etiquette. The strip, drawn by Ralph Reese, mined incongruous material (including alcoholism and miscarriage) to deliver a gag at the end of every instalment. ${ }^{51}$ One Year Affair began in 1973 and by the time the strips were collected as a small landscape book in September 1976 Preiss had written two titles in BPVP's Fiction Illustrated series. The biography at the back of the One Year Affair book asserts that Preiss's "adult graphic novels ... had been acclaimed as an important step forward for the comics medium," rather ignoring the internecine battles that Fiction Illustrated triggered within the comics world. ${ }^{52}$

BPVP brought comics creators together to deliver books to publishing houses as finished packages. Preiss sometimes wrote these books himself, or he paired up writers and artists, or he bought the rights to creative properties that other creators developed under his editorial control. ${ }^{53}$ Preiss operated as a book packager and not a self-publisher on the basis that if you only published a few books at a time, the resources invested were not likely to recoup adequate profit; he pursued multiple projects simultaneously, which, as we will see, stretched the time he was able to devote to each book. Preiss had reputational reasons for working with established publishing houses too:

To say that Harcourt Brace Jovanovich has published comics is a step forward for the medium, because that is saying that a major publishing house will commit themselves to doing comics. But to publish myself would mean, well, here's this guy who loves comics just like all the other guys who love comics... 54

A letter to The Comics Journal fanzine latched onto BPVP as a pioneering model for comics "aimed at the adult market." Fan Tony Robertson admired how BPVP joined creative talents together and agreed profit-sharing deals with publishers, calling Preiss "the first producer ... in graphic stories" $" 55$ (the latter phrase a common synonym for comics in the

\footnotetext{
${ }^{50}$ Preiss, Interview with G. Olshevsky, 92-99.

${ }^{51}$ Ellin Stein, That's Not Funny, That's Sick: The National Lampoon and the Comedy Insurgents Who Captured the Mainstream (New York: Norton, 2013), 172-73.

${ }^{52}$ Byron Preiss, writer, and Ralph Reese, illustrations, One Year Affair (New York: Workman Publishing, 1976), back matter.

${ }^{53}$ Alex Jay, Interview with the Author, 29 Oct. 2014.

${ }^{54}$ Preiss, Interview with G. Olshevsky, 99.

${ }^{55}$ Robertson, Letter, 17.
} 
period). Preiss would have approved of the analogy, aspiring as he did for comics to operate on the same level as films and books, a sentiment he shared at the 1977 San Diego ComicCon on a panel about the "Future of Comics." The graphic story producer asserted most stories combining images and words "to date -with a few notable exceptions - have been unsophisticated." He told the Comic-Con audience that future releases would draw "upon sophisticated concepts which are ordinarily filtered out or watered down in the more usual comic media"; Preiss added that his next book would extend the "graphic language" developed in Fiction Illustrated. ${ }^{56}$

Preiss's example of publishing with Harcourt Brace Jovanovich (HBJ) was an indirect allusion to his own "entrepreneurial packaging ability"57 in striking a deal with HBJ-owned Pyramid Publications. Pyramid's Senior Vice President Norman Goldfind was a supporter of Preiss's efforts and Pyramid published two series of BPVP's books in the mid-1970s. The first, Weird Heroes, was a mixture of original prose novels and short stories in the style of early twentieth-century pulp fiction, illustrated by artists working in comics. Correspondence between Preiss and veteran creator Will Eisner evidences that the packager initially conceived of Weird Heroes as a series of comics narratives rather than illustrated prose. Contributors had reportedly committed to Weird Heroes in spite of the fact that any financial rewards would be slight or non-existent, which Preiss explained to Eisner as a necessary compromise to ensure the books were published. ${ }^{58}$ On other BPVP projects, though, creators comment it was hard to get paid and they went into "extraordinary debt."59

The second Preiss-produced series at Pyramid was Fiction Illustrated, "America's First Adult Graphic Novel Revue." ${ }^{\circ 0}$ The Fiction Illustrated books were referred to as "graphic novels" by fans and retailers ${ }^{61}$ and Preiss claimed that because one of them had been reviewed in the New York Times "on an equal footing with other books" his "new format" was recognized by the "straight periodicals ... on an equal level with regular books"; further,

\footnotetext{
${ }^{56}$ Preiss, Interview with G. Olshevsky, 92-94.

${ }^{57}$ Harlan Ellison, Interview with Gary Groth, TCJ, 53 (Winter 1980), 87.

${ }^{58}$ Byron Preiss, Letter to Will Eisner, c.1974, in WEE 1, Folder 23, Will Eisner Papers, Billy Ireland Cartoon Library and Museum, Ohio State University, Columbus, OH.

${ }^{59}$ Howard V. Chaykin, Email to the Author, 23 April 2018; Samuel Delany, Email to the Author, 16 April 2018.

${ }^{60}$ This first appears in Byron Preiss, writer and editor, and Stephen Fabian, illustrations, Starfawn (New York: Pyramid, 1976), back cover.

${ }^{61}$ Advert for Bud Plant's Comics and Comix "New for August," The Nostalgia Journal, 28 (Sept. 1976), 9; advert for Bud Plant's Comics and Comix "New for August," TCR, 136 (Oct. 1976), 28-29; "Visual Publications," TCR, 126 (Jan. 1976), 12; Art Scott, "Times are Tough, Huh, Bud?" CAPAalpha, 139 (May 1976), [1.67].
} 
the audience for them was "growing." 62 Schlomo Raven (1976), the first Fiction Illustrated volume, was written by Preiss with art by Tom Sutton. ${ }^{63}$ Preiss's introduction contended the series was important because it constituted novel-length graphic stories that a "major publishing house" was marketing to "adults not adolescents." 64 Preiss also wrote the second volume, the SF odyssey Starfawn (1976), with art by Stephen Fabian. Preiss's introduction to Starfawn inserted Fiction Illustrated into the debates over creators' rights pulsing away in the 1970s comics world, drawing attention to Jerry Siegel and Joe Shuster's legal struggle for recognition and financial recompense for creating Superman. Preiss hailed Fiction Illustrated's relations of production as evidence of the victory of creators' rights: what "Siegal [sic] and Shuster had to fight for is what FICTION ILLUSTRATED has rightfully obtained from the start. ... Credit for the writer and artist, profit-sharing and valuable promotion are all part of the effort behind America's first adult graphic novel revue." ${ }^{65}$ BPVP trumpeted Fiction Illustrated as "important proof" that "the comic book is being considered as a commercially viable and intellectually respectable form of adult literature."

The Fiction Illustrated books made extensive use of first-person verbal narration. Schlomo Raven contained two parodies of hard-boiled crime fiction, specifically Chandler's and Hammett's Hollywood adaptations. The two stories are infused with wisecracks, oneliners, and surreal interjections, but while they read like comics, the prose narration between panels is substantial; the second story in Schlomo Raven starts with six pages of verbal preamble. At the beginning of Starfawn (1976) the Starship Destiny heads out to search for alien life and to study cosmic rays; official record keeper Daystar Stern introduces the mission and crew members with a verbal narration outside the panels that comments on the events shown within them. In this instance, Fiction Illustrated's predilection for prose-heavy first-person narration is made legible as the reader listening to Stern's report. The 'Captain's Log' from the television series Star Trek is the obvious point of reference, just as in the first and third Fiction Illustrated books the first-person narration was rendered comprehensible as a convention of hard-boiled detective fiction and film noir.

\footnotetext{
${ }^{62}$ Preiss, Interview with G. Olshevsky, 96.

${ }^{63}$ Byron Preiss, writer and editor, and Tom Sutton, illustrations, Schlomo Raven (New York: Pyramid, 1976).

${ }^{64}$ Preiss, Introduction, Schlomo Raven, [10].

${ }^{65}$ Byron Preiss, Introduction, Starfawn, [7].

${ }^{66}$ Preiss, Introduction, Schlomo Raven, [10].
} 
The third Fiction Illustrated book was Steranko's Chandler: Red Tide (1976) ${ }^{67}$ and the fourth and final instalment was Preiss and Ralph Reese's Son of Sherlock Holmes, published in January $1977 .{ }^{68}$ The digest-sized Schlomo Raven and Starfawn, distributed to bookstores and newsstands, seemed to lose sales because of their dimensions, "lost in a sea of larger and better produced magazines." 69 A reviewer noted that "newsdealers persist in displaying [Schlomo Raven] with the Archie digests."70 To rectify this situation, Chandler was released as a $\$ 1$ digest-sized softcover, a "Deluxe Edition" large paperback (\$4.95), and a signed, numbered bookplate edition $(\$ 7.50)$. The revenue on the larger books proved greater than the digests and Son of Sherlock Holmes was only published as a large softcover retailing at $\$ 4.95 .^{71}$ As well as being described as a graphic novel, Chandler's cover proclaimed it was a "Visual Novel"; this was how Steranko referred to it and the term "visual novel' became closely associated with Preiss's prose-heavy books. ${ }^{72}$

Norman Goldfind had been instrumental in ensuring Pyramid took on Fiction Illustrated and when he left to found the Baronet Publishing Company BPVP began packaging books for Goldfind's new enterprise. ${ }^{73}$ Three books appeared, The Illustrated Roger Zelazny (February 1978), The Illustrated Harlan Ellison (December 1978), and the first volume of The Stars My Destination (March 1979). ${ }^{74}$ The first two were adaptations of stories by noted SF authors, some of which adopted comics conventions, some of which added illustrations to the words, but both books were advertised as collections of "graphic stories" ${ }^{\prime 75}$ nonetheless. The Illustrated Roger Zelazny was issued as a $\$ 9.95$ softcover and as a signed, numbered edition of 2,500 copies (\$14.95 each) and The Illustrated Harlan Ellison was released as an $\$ 8.95$ softcover and a signed, numbered edition of 3,000 copies retailing at $\$ 14.95 .^{76}$ The Illustrated Roger Zelazny was BPVP's biggest success with graphic story

\footnotetext{
${ }^{67}$ Steranko, Chandler: Red Tide (New York: Pyramid, 1976).

${ }^{68}$ Byron Preiss, writer and editor, and Ralph Reese, illustrations and colours, Son of Sherlock Holmes (New York: Pyramid, 1977).

${ }^{69}$ Gary Brown, "Ibid," CAPA-alpha, 145 (Nov. 1976), [2.82]. See also Scott, "Times are Tough, Huh, Bud?" (May 1976), [1.67].

${ }^{70}$ Mark Burbey, Review of Schlomo Raven, RBCC, 126 (April 1976), 29.

71 "Comixscene," Mediascene, 21 (Sept.-Oct. 1976), 24.

${ }^{72}$ Martin L. Greim, "Crusader Comments," TBG, 180 (29 April 1977), 18.

${ }^{73}$ Ken Bruzenak, "Is There 3D in Your Future?" Mediascene, 31 (May-June 1978), 19.

${ }^{74}$ Roger Zelazny, writer, Byron Preiss, editor and adaptor, and Gray Morrow, illustrations, [with pencils for one story by Michael Golden,] The Illustrated Roger Zelazny (New York: Baronet, 1978); Harlan Ellison, writer, Byron Preiss, editor, and various artists, The Illustrated Harlan Ellison (New York: Baronet, 1978); Alfred Bester, writer, Byron Preiss, adaptor, and Howard Chaykin, artist, The Stars My Destination (New York: Baronet, 1979).

${ }^{75}$ Advert for Bud Plant (March 1978 catalog [sic] \#14), TCJ, 39 (April 1978), 44.

${ }^{76}$ Advert for Monkey's Retreat Retail-Mail Order, TBG, 257 (20 Oct. 1978), 46.
} 
publishing, reissued as a Science Fiction Book Club edition (July 1978) and a mass-market paperback from Ace Books in April 1979. That month BPVP announced the hardcover edition of Illustrated Roger Zelazny had sold out and 20,000 softcover copies had been printed. ${ }^{77}$ The Stars My Destination adapted the first part of Alfred Bester's 1956 novel, with popular comics artist Howard Chaykin providing the art and Preiss organizing the page layouts and words. In 1978 Preiss also produced two "graphic novels"78 for other publishers; the first was Empire, written by SF luminary Samuel R. Delany and illustrated by Chaykin. ${ }^{79}$ Advertisements boasted the print run for the $\$ 9.95$ paperback would be 50,000 copies, with 1,500 signed, numbered hardcovers retailing at $\$ 24$ each. ${ }^{80}$ The second was an adaption of Theodore Sturgeon's SF novel More than Human (1953) by writer Doug Moench and artist Alex Nino, published by Heavy Metal and distributed by Simon and Schuster. ${ }^{81}$

A second volume of The Stars My Destination was printed but never released. Baronet suspended publishing activities in 1980 because of "financial setbacks" but this was "nothing to do" with sales on the first volume (60 percent of 12,500 softcovers sold) ${ }^{82}$ Fan Kevin C. McConnell tried to rouse his peers in a show of solidarity with the publisher who had "done much to advance the graphic novel form by showcasing the fine productions of Byron Preiss, as well as such unprecedented works as Will Eisner's [1978 graphic novel] $A$ Contract with God." McConnell entreated his peers "to obtain a copy of Volume One [of The Stars My Destination] and savor it." He even printed Baronet's address so readers could express their interest in buying a second volume ${ }^{83}$ (Marvel eventually published a complete edition of The Stars My Destination graphic novel in 1992).

Even before Baronet's financial problems, Preiss made a direct address to fandom to buy his products. This was in a piece he wrote for The Comic Reader in September 1978, which framed BPVP's books as "an important step forward" for comics, an evolutionary leap that included other pioneering texts such as Art Spiegelman's experimental collection Breakdowns (printed in 1977, distributed in 1978). Preiss wrote that fans must support

\footnotetext{
${ }^{77}$ Advert for The Illustrated Roger Zelazny by Gray Morrow, TCR, 167 (April 1979), 28.

${ }^{78}$ Advert for BPVP, Mediascene, 31 (May-June 1978), 16.

${ }^{79}$ Samuel R. Delany, writer, and Howard V. Chaykin, artist, Empire: A Visual Novel (New York: Berkley Windhover, 1978).

${ }^{80}$ Advert for Supergraphics, TBG, 230 (14 April 1978), 76; advert for the Monkey's Retreat RetailMail Order, 46.

${ }^{81}$ Theodore Sturgeon, writer, Doug Moench, adaptor, and Alex Nino, illustrations, More than

Human: The Graphic Story Version (New York: Heavy Metal, 1978).

82 "Newswatch," TCJ, 55 (April 1980), 24.

${ }^{83}$ Kevin C. McConnell, "Disappointment My Destination," TCJ, 57 (Summer 1980), 4.
} 
"expensive books of comic art," whose costs made them risks for their publishers, if "comics are to grow":

If we are to reshape the nature of the economic systems of the medium -- pay royalty fees, subsidiary rights -- and reasonable sums of money to the people who make the comics, then we must look in a direction other than the constantly escalating $50 \varnothing$ newsprint comic book. The technologies of color web offset printing these days are such that the quality control is minimal or non-existant. [sic] ... With the high-priced illustrated books, we are able to preserve the artistic work and compensate the artist in relation to actual sales. ${ }^{84}$

It seems odd that Preiss saw his books as comparable to the self-conscious modernist experiments in Breakdowns, but for Preiss what he shared with Spiegelman was a refusal to take the language of comics for granted:

[A]long with the medium come certain conventions which people have learned in order to interpret the stories they read. The question is how can these conventions be restructured or redeveloped, how can you teach people to relearn the visual responses they have towards comics. These are extremely important things to take into account if you want to talk about the medium going anywhere.... ${ }^{85}$

Precisely because of his desire to reach non-comics readers by redeveloping the conventions of comics, fans gave Preiss a vicious reception.

\section{"Down with Byron Preiss!"86}

As cultural studies scholar John Fiske notes, fans "discriminate fiercely" about whom and what belongs within the remit of their collectively constructed fandom. A major "criterion of discrimination" is authenticity. ${ }^{87}$ The way that the words in Preiss's graphic novels occupied more space than the images, the way he minimized or eliminated speech balloons and handwritten lettering, these were all seized upon as evidence of the books' - and therefore his personal - inauthenticity. One of the few comics critics to write about BPVP's texts, R. C. Harvey, argues Steranko's Chandler (1976) should not be considered a "graphic novel" because "the pace of the story is controlled by the prose that runs in uniform columns under

\footnotetext{
${ }^{84}$ Byron Preiss, “An Opinion,” TCR, 160 (Sept. 1978), 14.

${ }^{85}$ Preiss, Interview with G. Olshevsky, 96.

${ }^{86}$ Steven Rowe, "MCs," CAPA-alpha, 170 (Dec.1978), [1.108].

${ }^{87}$ John Fiske, "The Cultural Economy of Fandom," in Lisa A. Lewis, ed., The Adoring Audience: Fan Culture and Popular Media (London: Routledge, 1992), 34-37.
} 
the pictures." While the "pictures create the story's mood ... they add no new information to the story." ${ }^{\prime 8}$ In fact, Steranko told the fan press in 1977 his intention was to move away from comics and exploit a "new format" in "adult books." 89 Nonetheless Harvey's point was shared by a multitude of fans and creators who called the Fiction Illustrated books "phoneycomics" 90 and criticized the series on the grounds it "hardly qualifies as comics" 91 and that by claiming them as such BPVP was going to "set comics back forty years." 92 One fan snarled, "When the adult graphic novel is produced, it won't be in this fashion." 93 BPVP became a byword amongst fans for transgressive word-image combinations. ${ }^{94}$

Samuel Delany recollected Preiss telling him that Empire would have no speech balloons because "they made things look too comicy." 95 This was the substance of what Preiss told convention-goers in 1977, that "separate, type-set text was necessary for commercial reasons, namely to impress publishers and get a foot in the door." 96 Steranko concurred this was required to appeal to an older audience. ${ }^{97}$ Yet it caused other professionals to wonder if the company was "sort of embarrassed"98 about the medium: if BPVP was committed to comics, why did it compromise one of its core formal principles? Fan Ron Harris was a vocal antagonist of BPVP in the monthly mailings of the amateur press association CAPA-alpha, calling Preiss a "snob" because he "simply couldn't convince himself that it was "classy' to publish comic books." ${ }^{99}$ Harris pointed out that the packager "consistently misspells Siegel's name," 100 implying Preiss had blown his audition to be considered an authentic member of fandom. Fiske reminds us that boundary policing within

\footnotetext{
${ }^{88}$ Harvey, Art of the Comic Book, 109.

${ }^{89}$ Steranko qtd. in Greim, "Crusader" (29 April 1977), 18; James Steranko, Interview with George Olshevsky, Collector's Dream, 1, 5 (Summer 1978), 86.

${ }^{90}$ Doug Moench, Interview, RBCC, 147 (Feb. 1979), 47.

${ }^{91}$ Neal Pozner, "What th- Anyhate," CAPA-alpha, 141 (July 1976), [2.106-07]. See also Steve Gerber, Interview with Gary Groth, TCJ, 41 (Aug. 1978), 37; Jay L. Zilber and Ken Gale, "Weird Thoughts in the Twentieth Century," CAPA-alpha, 144 (Oct. 1976), [2.61]; Art Scott, "Times are Tough, Huh, Bud?" CAPA-alpha, 147 (Jan. 1977), [1.19]; Mark Evanier, "Feetlebaum," CAPA-alpha, 150 (April 1977), [2.17]; G. Groth qtd. in Ellison, Interview with G. Groth, 90.

${ }^{92}$ Harris, "Argh" (Sept. 1978), [1.52, 1.60].

${ }^{93}$ Jim Korkis, "Harlequin," CAPA-alpha, 148 (Feb. 1977), [2.44].

${ }^{94}$ Kim Thompson, Review of Future Day by Gene Day, TCJ, 55 (April 1980), 32.

${ }^{95}$ Samuel Delany, "Refractions of Empire: The Comics Journal Interview," 29, in Box 50, File 6, Samuel R. Delany Papers, Howard Gotlieb Archival Research Center, Boston University. These holdings are referred to hereafter as the 'Delany Papers.'

${ }^{96}$ Christopher Melchert, "Onde de Choc [Shockwave]," CAPA-alpha, 155 (Sept. 1977), [1.97]. See also Kurtzman with Barrier, From Aargh! To Zap!, 75.

${ }^{97}$ Harris, "Argh" (Sept. 1978), [1.59].

${ }^{98} \mathrm{Jim}$ Shooter, Interview with Gary Groth, TCJ, 60 (Nov. 1980), 83.

${ }^{99}$ Harris, "Argh" (Sept. 1978), [1.60].

${ }^{100}$ Ron Harris, "Aargh," CAPA-alpha, 140 (June 1976), [1.77].
} 
fan communities requires getting such details right: the display of knowledge "helps to distinguish a particular fan community (those who possess it) from others (those who do not)...." Systematic studies of comics fans bear this out, that the exercise of "true' expertise" is the mark of a "proper" fan. ${ }^{102}$ Matthew J. Pustz's Comic Book Culture: Fanboys and True Believers (1999), an ethnographic study of fandom, notes that due to the lack of wider social esteem accredited to comics a "kind of siege mentality" operates amongst fans. As a consequence, newcomers are likely to face challenges designed to gauge the extent of their comics knowledge. These challenges work "as a kind of secret handshake, allowing a new person with the requisite expertise into a group where fannish experiences are openly shared." 103

Ron Harris asserted Preiss's presence in the comics world was unearned, alleging he only "got into mainstream comics through the back door ... by virtue of some educational work he did with Jim Steranko," and that BPVP's books were not "real graphic stories."104 In a letter to The Comics Journal Dan Recchia sardonically proclaimed that "the Byron Preiss Golden Books for Adults ... deny being comic books, as if they were before the HUAC committee," 105 a lurid example of the accusations thrown at Preiss. Calling them "Golden Books for Adults" suggested BPVP was publishing children's illustrated books and ludicrously calling them adult reading matter. More perniciously, Recchia framed Preiss's books as witnesses brought before Senator Joseph McCarthy, disavowing a forbidden past (as comics) and betraying former allies in order to buy grace in the eyes of a hostile society. In 1980 one of Preiss's defenders, SF writer Harlan Ellison, ventriloquized BPVP's critics thus: "This schmuck Preiss ... has wandered into our holy and sanctified grove and is pissing on the trees...."106 Here Ellison encapsulates the attempt by fans to render Preiss a trespasser who lacks the respect and knowledge necessary to enter the "sanctified" vale of fandom.

There was another way in which BPVP was adjudged to have transgressed the rules and codes governing the comics world: one could take comics seriously, but self-importance was to be guarded against. Proclaiming that one's publications were going to cause a revolution in the status of comics was a sure way to earn enmity. One fan articulated this rule out loud: "comics projects ... that vigorously insist they be given due recognition are very

\footnotetext{
${ }^{101}$ Fiske, "The Cultural Economy of Fandom," 43.

${ }^{102}$ Mel Gibson, Remembered Reading: Memory, Comics and Post-War Constructions of British Girlhood (Leuven: Leuven University Press, 2015), 170.

${ }^{103}$ Ibid., 162; Pustz, Comic Book Culture, 114.

${ }^{104}$ Harris, "Aargh" (June 1976), [1.75]; Harris, “Argh” (Sept. 1978), [1.60-61].

${ }^{105}$ Dan Recchia, Letter, TCJ, 51 (Nov. 1979), 25.

${ }^{106}$ Ellison, Interview with G. Groth, 8.
} 
rarely those which truly deserve it." ${ }^{107}$ Fandom lambasted Preiss for being "pompous"108 and having "delusions of grandeur." 109 Just as BPVP was associated with abandoning comics conventions, the company became synonymous with self-promotion. ${ }^{110}$ Even sympathetic readers complained that Preiss "spends so much time talking about concepts and credits and people and editorializing" when he should "let us judge it for ourselves." 111 Preiss responded to criticisms with greater hyperbole, taking out a five-page advertisement claiming that BPVP was the culmination of ten years of hoping and dreaming:

\section{8}

We had Steranko on S.H.I.E.L.D, Adams on Deadman, Kirby at Marvel [sic] and a dream - comics for adults, sophisticated graphic stories on high-quality paper by the best writers and artists in the field.

1978

Dreams come true. Visual Publications and a dozen talented artists change the face of the graphic story medium. ${ }^{12}$

Unfortunately, by italicizing 'Marvel' and making it out to be a series and not a company, Preiss's knowledge of comics - the password needed for him to be accepted within fandom was erroneously expressed once more.

Preiss's status as persona non grata was evident in the rules of a competition that ran in The Comics Journal: “Anyone [is] eligible to enter: Stan [Lee], Jenette [sic] [Kahn] - heck, even Byron Preiss. Really!" 113 Hostility towards BPVP's books was so widespread in The Comics Journal that a fan noted of issue fifty-seven, "For once someone didn't put down The Stars My Destination." "114 Noting it was "trendy to pin Byron to the wall" the writer Harlan Ellison was enraged by "the shit I read that's directed toward this guy." Ellison explained it had "hurt" Preiss, and that the visual producer "gets very defensive and very crazy and he tries to fight back" by responding to the criticisms. ${ }^{115}$

Preiss had other defenders and Harvey Kurtzman's foreword to Schlomo Raven praised its "format" as "a paperback comic book," though Kurtzman did not refer to its

\footnotetext{
107 Jay Zilber, "First Look," TCJ, 48 (Summer 1979), 64; italics in original.

${ }^{108}$ Harris, "Aargh" (June 1976), [1.75].

${ }^{109}$ Korkis, "Harlequin," (Feb. 1977), [2.44].

110 Zilber, "First Look," 64. See also Bob Soron, "Grooble!" CAPA-alpha, 184 (Feb. 1980), 15 [Insert].

${ }^{111}$ Gary Brown, "Ibid," CAPA-alpha, 143 (Sept. 1976), 16 [Insert]. See also Neal Adams, Interview with Gary Groth, TCJ, 43 (Dec. 1978), 43-44.

${ }^{112}$ Advert for BPVP, TCR, 159 (Aug. 1978), 20-24.

113 "First Annual Future Events Contest," TCJ, 53 (Winter 1980), 65.

${ }^{114}$ Kevin DeWitt Reid, Letter, TCJ, 60 (Nov. 1980), 30.

${ }^{115}$ Ellison, Interview with G. Groth, 87.
} 
content. ${ }^{116} \mathrm{He}$ was a judicious choice to offer prefatory words, since his work as a writer and artist at 1950s publisher EC was valorized by fans as some of the most significant comics ever produced. As comics historian Amy Kiste Nyberg put it in 1998, "If there is a 'canon' of comic books, E.C. Comics may be found at the head of the list." 117 Ever since they were published Kurtzman's war stories have been praised for combining "careful attention to historical detail, thoughtful and ironic writing, and a sense of moral outrage,"118 and EC was also known for provocative and thought-provoking crime, horror, and SF comics. EC's reputation with later generations of fans was undoubtedly enhanced by its fate: in 1954 most of the major publishers formed the Comics Magazine Association of America and implemented a censorship board to stave off the threat of government regulation. EC had achieved strong sales but, with the horror genre prohibited and others profoundly restricted, the company struggled in an industry whose products were limited "to a supervised, puerile level..." EC essentially withdrew from the periodical comic market and its later attempts to reach beyond comics ("Picto-Fiction" magazines that combined images and text with the emphasis on the latter) sold "dismally" and were soon cancelled. ${ }^{119}$ Interestingly, EC's "Picto-Fiction" broadly resembled BPVP's books in the 1970s; more significantly, Kurtzman represented a perceived golden age when US periodical comics could be disrespectful towards authority, could imply sexual intercourse, and entertain moral ambiguity - in other words, when American comics could be adult reading material.

Like Kurtzman, many readers of BPVP's publications responded favourably to their book-like qualities, though not all felt Preiss exploited them successfully. ${ }^{120}$ Preiss, nonetheless, was given credit for realizing projects most fans and creators just talked about ${ }^{121}$ and for representing the kind of direction comics needed to go in. ${ }^{122}$ One fan thought that

\footnotetext{
${ }^{116}$ Harvey Kurtzman, Foreword, Schlomo Raven, [7].

${ }^{117}$ Amy Kiste Nyberg, Seal of Approval: The History of the Comics Code (Jackson: University Press of Mississippi, 1998), xi.

${ }^{118}$ Wright, Comic Book Nation, 143.

${ }^{119}$ Ibid., 154-79. See also Nyberg, Seal of Approval, 117-24, and for the British context, Martin Barker, A Haunt of Fears: The Strange History of the British Horror Comics Campaign (London: Pluto Press, 1984).

${ }^{120}$ Todd Goldberg, Letter, TCJ, 44 (Feb. 1979), 21; Louis Morra, "Nonsubstantiality," CAPA-alpha, 141 (July 1976), [2.14]; Jeffrey H. Wasserman, "Jāch Spake!” CAPA-alpha, 145 (Nov. 1976), [1.31]. See also the reviews of BPVP's books in RBCC: Burbey, Review of Schlomo Raven, 29; James Van Hise, Review of Starfawn, RBCC, 127 (May 1976), 13.

${ }^{121}$ Howard Chaykin, Interview, TCJ, 51 (Nov. 1979), 55; Harlan Ellison, Interview with James Van Hise, $R B C C, 151$ (Aug. 1980), 21.

${ }^{122}$ A letter from Craig Ledbetter to $T C J, 45$ (May 1979) made a similar point: "Until the majority of the field begins to take the shape that Byron Preiss is pushing I'm afraid that comics will languish in
} 
with More than Human BPVP had produced its "closest [effort] to traditional comics" and, taken with other 1970s novelization projects, was ushering in an era when comics would "[break] out into the big wide world outside our little ghetto."123

\section{The Empire of Byron Preiss}

Conversations about Empire began in the winter of 1976 when Preiss, Chaykin, and Delany sat down to devise a visual novel. ${ }^{124}$ Delany and Chaykin had looked to collaborate since the late 1960 s and the artist and Preiss were old school-friends. ${ }^{125}$ Around this time Chaykin was enjoying the success of the Star Wars comic based on George Lucas's 1977 film. The licence was awarded to Marvel without a fee, but Lucas had two stipulations: to maximize publicity the comic had to appear before the film's release and the artist had to be Chaykin. Initially the comic sold 57 percent of its print run, solid but not spectacular. Once the film was released sales of the comic rocketed and the first issue eventually sold over a million copies. ${ }^{126}$ By the time of Empire's publication in October 1978 Chaykin had bowed out of monthly work commitments at Marvel and DC in order to pursue independent projects. ${ }^{127}$ The mixed media art from Empire which Chaykin previewed on the convention circuit was greeted with palpable enthusiasm. ${ }^{128}$ Fans and reviewers had taken umbrage at Preiss writing three of the Fiction Illustrated books but now scripting duties were turned over to an award-winning SF author acclaimed in the New York Times Book Review. ${ }^{129}$ At the 1977 San Diego Comic-Con, Preiss asked how many people wanted the forthcoming Empire to use speech balloons, suggesting he was sensitive to the fans' anger at the lack of balloons in BPVP's previous offerings. ${ }^{130}$ Preiss told The Comic Reader this new project was "what people have been

the ghetto" (22). See also Mike Friedrich, Interview with Mal Burns, Graphixus, 2 (March 1978), 22; Rick Marschall, Interview, TCJ, 52 (Dec. 1979), 57.

${ }^{123}$ Rich Fifield, "Zeta Beam," CAPA-alpha, 176 (June 1979), [2.23].

${ }^{124}$ Byron Preiss, Foreword, Empire, [4].

${ }^{125}$ Samuel R. Delany, Interview, TCJ, 48 (Summer 1979), 40.

${ }^{126}$ Dave Dykema, "1977: A Renewed Hope," in Jason Sacks, ed., American Comic Book Chronicles:

The 1970s, 1970-1979 (Raleigh, NC: TwoMorrows Publishing, 2014), 205-6.

${ }^{127}$ Arlen Schumer, "The New Superheroes: A Graphic Transformation," Print, 42, 6 (Nov.-Dec.

1988), 119. A useful summary of Chaykin's career up to the early 1980s is provided in Costello, Neon Visions, 19-21, 45-47.

${ }^{128}$ Jeff Gelb, Letter, $T B G, 255$ (6 Oct. 1978), 8-9; Murray Bishoff, "A Report On The Chicago Comic Convention," TBG, 247 (11 Aug. 1978), 50.

${ }^{129}$ Gerald Jonas, "S.F.," New York Times Book Review, 16 Feb. 1975, 27.

${ }^{130}$ Melchert, "Onde de Choc," [1.97]. 
asking for and that it's in the comic medium." ${ }^{31}$ Empire should have been BPVP's finest hour yet Preiss was accused of ruining a good idea by being an obtrusive presence in the construction of the text. This time the accusation came from his collaborators as well as the fans.

The book's narrative involves a band of rebels jumping from one action-packed episode to the next, searching for the fragments of a mysterious technology that, when pieced together, will collapse the information control system that the draconian Kūndūke empire uses to rule the universe. Into this story Delany interwove elements of catastrophe theory; from mathematicians to Star Wars fans, Empire had the potential to appeal to multiple audiences, and it was published in hardcover and softback editions by Berkley Windhover. Before publication Mediascene reported that David Hartwell, Berkley's SF editor, was so confident that this "breakthrough novel in graphic story form" would be a hit the print run was planned for 50,000 copies. ${ }^{132}$ Preiss extended the marketing tactics he adopted with Fiction Illustrated. Advertisements, posters, and convention publicity identified Empire as a sophisticated reading experience in terms of appearance (Chaykin's painted art, typeset lettering, large pages, and square-bound format) and subject matter (Delany's use of catastrophe theory). BPVP claimed to have achieved another leap forward in the history of comics and Preiss promoted it with techniques he hadn't tried with Fiction Illustrated, such as previewing Empire in the popular comics anthology magazine Heavy Metal.

While the marketing announced "Delany delivers a true graphic novel"133 the writer protested in a 1979 interview with The Comics Journal that "I never thought of it as such. ... I think of it as a comic book...."134 Bob Toomey's The Comics Journal review sneered "it is not a novel. It's an expensive comic book, and a pretty bad one at that." Toomey hated Empire, writing that the plot was predictable and illogical and the dialogue was "terrible." What bewildered Toomey was Preiss's page layouts and Chaykin's acquiescence: every page of Empire was divided into three uniform vertical panels or three uniform horizontal panels. ${ }^{135}$ This was only a template, so there were full-page spreads as well as pages where the three panels were subdivided or amalgamated. The fan-orientated periodical Mediascene rhapsodized about these formal parameters as a "departure from accepted comic line art standards," but then, Mediascene was owned by Preiss's friend Steranko. Reading Empire

\footnotetext{
131 "Visual Publications," TCR, 137 (Nov. 1976), 9.

132 "Empire," Mediascene, 29 (Jan.-Feb. 1978), 28-29.

${ }^{133}$ Ibid., 28-29.

${ }^{134}$ Delany, Interview, 71

${ }^{135}$ Bob Toomey, "Vanishing Point," TCJ, 45 (March 1979), 32.
} 
was supposedly a cleaner and more holistic experience than reading other comics because it was "uncluttered by word balloons or crude hand-lettering, ... utilizing a special floating-axis page structure, designed by Byron Preiss, to integrate art and type into a totally original unified form."136 Toomey's position was that varied page layouts were an essential component of comics storytelling: panels of different shapes and sizes accelerate and decelerate the pace of the narrative as appropriate, whereas Empire's page layouts were a "definite step backward," "a straitjacket on the artwork" that produced a monotonous reading experience. The monotony was worsened by the use of uniform type instead of hand-drawn lettering. A lot of the type was placed outside the panels, and dialogue might start above one panel and end beneath another, leading Toomey to complain it was "difficult to tell who's speaking." 137 Conversely, the few newspaper reviews that Empire received understood it as a coherent, thrilling reading experience. St. Louis Post-Dispatch called it "a visual tour de force" and thought the "three column vertical or horizontal grid" layout "more dramatic and flexible" than the "box panels" of periodical comics. ${ }^{138}$ Empire was reviewed elsewhere as "an experiment to be applauded," 139 suggesting that Preiss's aim of making comics more legible for non-comics readers had been, at the very least, partially successful.

In his interview in The Comics Journal Delany remarked that "Byron's insistence on the vertical-horizontal thing was a mistake," as was the proscription on speech balloons, since they unnecessarily restricted the visual "language" of comics available to the creators. ${ }^{140} \mathrm{By}$ 1979 Preiss had, apparently, realized the floating-axis design was "not too good an idea."141 Surprisingly, The Comics Journal did not publish Delany's most strident thoughts:

[The] particular restrictions Byron, as packager, was coming up with seemed geared to sabotage the whole enterprise. All the iconic rhetoric of the medium that made it flexible, incisive, and articulate he wanted to cut out, and for what pretty much struck me as vague, pretentious, and ill-thought-through reasons. A lot of it, I think, came from that innate inferiority complex so many people in the administrative side of the comics industry walk around with daily. Their ideal is to do comics that look like anything but comics. That was the basic reason, I suppose, Byron had began by bringing me in, as a hot-shot writer from another, more respectable medium, in hopes

\footnotetext{
136 "Empire," 28-29.

${ }^{137}$ Toomey, "Vanishing Point," 32-33.

${ }^{138}$ Robert LaRouche, "Fantastic Visions," St. Louis Post-Dispatch, 4 March 1979, in Box 65, Folder 11, Delany Papers.

${ }^{139}$ Leo McConnell, "Worth Looking Into," Country News, 14 Dec. 1978, in Box 65, Folder 11 , Delany Papers.

${ }^{140}$ Delany, Interview, 41-43.

${ }^{141}$ Ibid., 71.
} 
I'd somehow magically turn the lowly comics form into something wondrous and new - and, above all, respectable. ${ }^{142}$

Delany reported that half the script had been rewritten and the verbal text was frequently positioned in the wrong place. "Byron had a lot of projects going at the same time, and although he paid as much attention as he could to each individual one, I think things just slipped up." As a result, the reader does not navigate the published pages in the way Delany intended, and some dialogue is attributed to the wrong characters. Preiss and Delany disagreed on where words should be positioned on the page and the two "had a battle royal over" over the first page. Preiss eventually deferred to Delany but the top of one panel was inexplicably severed. ${ }^{143}$ Pages [20] and [21] are the wrong way round, some dialogue is in quotation marks but not all, and Delany was forced to change his captions from the past tense to the present tense because of Preiss's selective rewriting. ${ }^{144}$

After seeing his interview in print, Delany wrote to The Comics Journal to ameliorate his criticisms, admitting that responsibility for the layouts was spread among many people and that collaborative work always brings a degree of confusion. Delany had returned to his script and on random sampling discovered 39 percent of his lines had been rewritten. Further, he praised Preiss for going about his projects without the cynicism dogging the big "commercial outlets." 145 And Delany had already stated in the summer 1979 interview he was broadly happy with Empire and, "for all the things that were done with it, I feel very much that it's still basically mine and Howie's story." 146

Having consulted a 1978 manuscript of Delany's script, on most occasions Preiss's changes to the dialogue did not make it less understandable, though Preiss sometimes mangled the poetry of Delany's sentence construction. For example, in the 1978 script the characters Qrelon and the Nizerine Eleyn jump into a pool to escape a Kūndūke massacre, and Delany had written, "Down the Nizerine swam, and down. And down Qrelon followed, into the side passage where a cold current tugs them along." Preiss simplified this to "Qrelon followed the Nizerine down, down, into a side passage where a cold current caught them..." [82]

In other places Preiss's editing tore holes in narrative logic. Page [58] of Empire is markedly different from Delany's script. This is the moment that the protagonists Wryn and

\footnotetext{
${ }^{142}$ Delany, "Refractions of Empire: The Comics Journal Interview," 29-30.

${ }^{143}$ Delany, Interview, 42-43.

${ }^{144}$ Delany, "Refractions of Empire: The Comics Journal Interview," 35-44.

${ }^{145}$ Delany, Letter, TCJ, 51 (Nov. 1979), 23.

${ }^{146}$ Delany, Interview, 71.
} 
Qrelon have alone on Qrelon's spacecraft Proteus after a succession of action-packed incidents. Both versions have the characters exchange lustful looks that change the relationship between them. In Delany's script, rebel fighter Qrelon encourages archaeology student Wryn to touch her, but after an ellipsis in the action during which the characters are physically intimate, neither is fully satisfied and Qrelon concludes, "Never mind, boy. Let's just split the blame and stay friends." 147 The published version has Wryn profess "Qrelon, you know I really like you a lot" and Qrelon returns his affection but decides "there's no time for things such as this" until their mission is complete. Preiss's editing, then, tried to maintain the sexual tension between the main characters, tension dispensed with by Delany's script. This jarred with Chaykin's art, since the panel showing the outside of the asteroid-pirates' base was rendered superfluous: the purpose of this panel was to signify the plot jumping forwards in time during the characters' sexual intercourse. In the final, published version it is unclear why Qrelon is suddenly missing her clothes and looking rueful.

One last example of how Preiss "imposed" his "ideas about how a plot achieves a certain kind of suspense" 148 can be found on pages [102-103]. At this point in the story Wryn is wandering inside the Kūndūke's frozen information system, called 'Ice,' searching for a means of uploading the Meta-Max demon into the heart of the system. When the Meta-Max reaches the centre of Ice it will sabotage the Kūndūke's rigid control of information throughout the universe. At the same time Qrelon has been captured and sadistic intelligence officer Loiptix tries to force her to pull a lever that will drop a section of crystal onto Wryn, thus ending the rebellion. The writer and artist originally conceived of a full-page spread and three vertical panels for this culmination of the narrative but "Byron ended up cutting off the bottom of the full page thing and dividing up the three panel sequence into whole lots of little panels." He created new panels out of the bottom of the full-page spread and by getting Chaykin to paint three more, so in the published version the action takes place over eight panels and not four. ${ }^{149}$ Preiss made these changes at the galley stage and, according to Delany, the alterations stem from a fundamental disagreement about the suspense generated by this scene. In the original, Wryn does not know about Loiptix's evil designs but Preiss thought this dramatic irony - where the reader knows the character has to hurry but Wryn doesn't - wasn't suspenseful enough. For it to be exciting, Wryn had to know his life was in danger. Delany recollected Preiss insisting "you have to put some of my kind of suspense in

\footnotetext{
${ }^{147}$ Delany, Journal with notes on "Empire" marked [1978?], in Box 56, Folder 12, Delany Papers.

${ }^{148}$ Delany, Interview, 43.

${ }^{149}$ Ibid., 43, 70.
} 
it"; at such a late stage on production, "anything that Byron 'tried' now would be in the finished book." ${ }^{50}$ Chaykin's new panel on [103] (the bottom left-hand corner) shows the information flow within Ice but with no regard for the events taking place - it seems to stand outside the narrative. Another new panel on [102], on the bottom right, depicts an empty chamber within Ice. These panels invite detached contemplation of Ice's interior corridors, not excitement. Delany confessed to The Comics Journal, "From this page to the next page I really don't know what's going on - I really don't!"151 Delany's tale of Preiss changing these pages immediately before production is supported by the fact that page [102] is the only one in the book violating the floating-axis template.

Fans had already complained that BPVP's artists were "strait-jacketed"152 and in the wake of Delany's Comics Journal interview Steven Rowe wondered "what will happen when the creative people will be allowed to create." 153 News of Preiss's revisions confirmed Rowe's prejudice that the graphic story producer's main contribution to BPVP's publications was to spoil them. The year before, Rowe wrote in CAPA-alpha, "Down with Byron Preiss! I read the except [sic] of EMPIRE in HM, and ... [the] figuration of the words was barbaric blame it on editor Preiss - he's an easy target." 154 Ron Harris complained of More Than Human that artist Alex Niño's “creativity" was so limited the artist was "hardly necessary at all." 155 Chaykin defended Preiss on the grounds that he worked hard, made things happen, and explored "technical avenues" that no-one else would. But when the artist described his working relationship with Preiss on The Stars My Destination it became clear that, against Chaykin's preference to lay out his own pages, Preiss gave Chaykin boards with the panels drawn in. Chaykin said he "had nothing to do with the layout[.] ... The book is Byron's. I illustrated the book." "156 Preiss's editing was criticized in Jim Dawson's review of The Illustrated Roger Zelanzy, which Dawson described as a "blatantly offensive" book omitting essential characterization from the original stories. Preiss had not so much adapted Zelazny's prose as he had "eviscerated" it, deleting parts without thinking of continuity or legibility. ${ }^{157}$ Even in the late 1970s atmosphere of The Comics Journal this was shrill language and Heavy Metal editor Julie Simmons complained Dawson's review was “a one-sided, unwarranted,

\footnotetext{
${ }^{150}$ Delany, "Refractions of Empire: The Comics Journal Interview,"49-51.

${ }^{151}$ Delany, Interview, 43, 70.

${ }^{152}$ Scott, "Times are Tough, Huh, Bud?" (Jan. 1977), [1.20].

${ }^{153}$ Steven Rowe, "The Savage Gentleman," CAPA-alpha, 179 (Sept. 1979), [84].

${ }^{154}$ Rowe, "MCs," [1.108].

${ }^{155}$ Harris, "Argh" (Sept. 1978), [1.58].

${ }^{156}$ Chaykin, Interview, 55, 66.

${ }^{157}$ Jim Dawson, Review of The Illustrated Roger Zelanzy, TCJ, 44 (Feb. 1979), 27-28.
} 
negligent piece of reporting[,] ... more like a personal vendetta toward Preiss \& co., than a factually based comment." 158

The reception of BPVP's books was, as Simmons commented, clouded in the atmosphere of vendetta and the perceived need to avenge Preiss's betrayal of comics. Reviewer Pierce Askegren called The Illustrated Harlan Ellison an "uneven melange" and wondered "how much of the finished product Ellison saw prior to publication." 159 Ellison defended Preiss's editorial changes on the grounds that the packager was torn between "publishers and printers and artists and writers and his own artistic sensibility." In this figuration Preiss was not the artful book packager but a creative worker pulled in several directions at once. ${ }^{160}$ On another occasion Ellison defended Preiss by stating he is "a producer" and "[p]roducers have to get the product out." The SF writer lampooned the fans' formulation of Preiss as a monster who "locks Howie Chaykin into a dark closet and beats him with a cat-o'-nine tails until he does shitty layouts," stating that if Delany or Chaykin had refused to compromise on Empire then Preiss would have backed down. ${ }^{161}$ This misses the point that Preiss had the final say because the pages were entrusted to him on their journey to the publisher.

\section{Conclusion}

BPVP's status as purveyor of "the latest graphic novels"162 was made possible by the era of blockbuster books and the power that packagers possessed in trade publishing during the 1970s. In October 1978 The Comics Journal reported that the commercial and critical success of Illustrated Roger Zelazny prompted Norman Goldfind, "publisher of Baronet Books, to give the go-ahead for additional titles. Most of them will undoubtedly follow the path set by previous releases of that type." One of the planned books was Will Eisner's "A Covenant [sic] with God and Other Tenement Stories...."163 What success BPVP enjoyed, then, was a fillip for the publication of the most famous graphic novel of the decade. But Preiss's working practices did not cohere with his avowed commitment to comics and to creators' rights, since he devised his company's projects and had the final edit. Because BPVP offered

\footnotetext{
${ }^{158}$ Julie Simmons, Letter, TCJ 47 (July 1979): 18.

${ }^{159}$ Pierce Askegren, “A Mixed Bag of Ellison,” TCJ 48 (Summer 1979): 30.

${ }^{160}$ Ellison, Interview with J. V. Hise, 21.

${ }^{161}$ Ellison, Interview with G. Groth, 88.

${ }^{162}$ Bruzenak, "Is There 3D in Your Future?" 19.

163 "Newswatch," TCJ, 42 (Oct. 1978), 8-13.
} 
the relatively rare opportunity to create book-format comics, major creators took the chance to work with Preiss, but - though they did collaborate with him after Empire - Delany and Chaykin felt he was more interested in profit than comics and neither continued their relationship with BPVP for much longer. ${ }^{164}$

In the 1970s Preiss was treated as an overenthusiastic outsider whose desire to bring comics into trade publishing stemmed from anxiety about his own position in relation to those spheres: he was judged guilty of paying insufficient fealty to the comics world and failing to live up to his enormous claims. Would Preiss have had greater success in the $1980 \mathrm{~s}$ if Baronet had not collapsed? Delany thinks he had "learned that you don't take something interesting and force [it] into a completely artificial form that is determined by being [as] little like comics as possible." 165 In the 1980s Preiss sold comics properties to Marvel's Epic imprint $^{166}$ and BPVP produced a few comics-related books such as Harvey Kurtzman's From Aargh! To Zap! Harvey Kurtzman's Visual History of the Comics (1991) but he would never again play such a prominent role in the novelization of this cultural form.*

\footnotetext{
* Dr Paul Williams is Senior Lecturer in Twentieth-Century Literature at the University of Exeter in the UK. He has written two books, Paul Gilroy (2012) and Race, Ethnicity and Nuclear War (2011), and he co-edited the collection The Rise of the American Comics Artist: Creators and Contexts (2010) with James Lyons. He is currently writing a monograph with the provisional title Novel Talk: Dreaming of the Graphic Novel in the Long 1970s,
}

\footnotetext{
${ }^{164}$ Samuel Delany, Emails to the Author, 16-18 April 2018.

${ }^{165}$ Ibid.; Moench, Interview, 43.

${ }^{166}$ Alex Jay, Interview with the Author, 29 Oct. 2014.
} 
forthcoming from Rutgers University Press. The research underpinning this article was generously supported by the Arts and Humanities Research Council. 